\title{
The Phylogenetic Position of Pseudoamycolata halophobica (Akimov et al. 1989) and a Proposal To Reclassify it as Pseudonocardia halophobica
}

\author{
H. P. MCVEIGH, ${ }^{1 *}$ J. MUNRO, ${ }^{2}$ AND T. M. EMBLEY ${ }^{1}$ \\ Microbiology Group, Department of Zoology, Natural History Museum, London SW7 5BD, ${ }^{1}$ and Department of \\ Natural Products Discovery, Glaxo Group Research, Greenford, Middlesex UB6 OHE, ${ }^{2}$ United Kingdom
}

\begin{abstract}
The genus Pseudoamycolata was proposed for actinomycetes which closely resembled Amycolata species in most phenotypic features but lacked a key chemotaxonomic marker, phosphatidylcholine. We sequenced the 16S ribosomal DNA of Pseudoamycolata halophobica and found that this organism is very closely related to the genus Pseudonocardia, which now contains all of the strains formerly classified as members of the genus Amycolata. In light of these data, we believe that the absence of a single chemical characteristic is not sufficient to justify forming a new genus, and we propose that Pseudoamycolata halophobica (Akimov et al. 1989) should be reclassified as Pseudonocardia halophobica. The type strain is strain DSM 43089.
\end{abstract}

The family Pseudonocardiaceae $(2,8)$ contains actinomycetes which lack mycolic acids and have chemotype IV cell walls (sensu Lechevalier and Lechevalier [16]). This taxon currently comprises the genera Actinopolyspora, Amycolatopsis, Saccharomonospora, Saccharopolyspora, Kibdelosporangium, and Pseudonocardia $(2,8,21)$. There are relatively few stable characteristics which can be used to distinguish among the different genera (6), but in at least some cases differentiation can be achieved by using phospholipid and menaquinone compositions $(7,17)$. For example, Amycolatopsis species contain phosphatidylethanolamine as a characteristic phospholipid (type PII phospholipid pattern [15]) and contain partially hydrogenated menaquinones with nine isoprene units as their major menaquinones $\left[\mathrm{MK}-9\left(\mathrm{H}_{2}, \mathrm{H}_{4}\right)\right](17)$. In contrast, members of the genus Amycolata, which otherwise look and behave like Amycolatopsis strains, contain phosphatidylcholine as well as phosphatidylethanolamine (phospholipid type PIII) and major amounts of hydrogenated menaquinones with eight isoprene units [MK-8( $\left.\left.\mathrm{H}_{4}\right)\right]$ (17). In 1989, a new genus, Pseudoamycolata, was proposed (1) for two strains which had been formerly classified as Amycolata autotrophica strains. The single species of this new genus strongly resembled Amycolata species in overall morphology and phenotype and contained MK-8 $\left(\mathrm{H}_{4}\right)$ as its major menaquinone. However, this organism lacked phosphatidylcholine, and absence of this single characteristic was judged to be sufficient to distinguish the new genus Pseudoamycolata.

Comparative analysis of $16 \mathrm{~S}$ rRNA sequences is currently the most powerful method for resolving higher taxonomic relationships among actinomycetes $(2,8,9,22)$. This approach has recently (21) been used to reexamine the phylogeny of members of the family Pseudonocardiaceae. The data obtained led to the proposal that the genera Amycolata and Pseudonocardia should be combined in a redefined genus Pseudonocardia; this proposal is strongly supported by overall phenotype (6). In this investigation we used 16S rRNA analysis to determine the phylogenetic relationship between Pseudoamycolata halophobica and the genus Pseudonocardia.

\footnotetext{
* Corresponding author. Mailing address: Microbiology Group, Department of Zoology, Natural History Museum, Cromwell Road, London SW7 5BD, United Kingdom. Phone: 071-938 9152. Fax: 071-938 8754. Electronic mail address: hpm@nhm.ic.ac.uk.
}

\section{MATERIALS AND METHODS}

Bacterial strains. The type strain of Pseudoamycolata halophobica, strain DSM 43089 , was grown at $25^{\circ} \mathrm{C}$ in Bennett's broth containing $0.1 \%(\mathrm{wt} / \mathrm{vol})$ yeast extract, $0.1 \%$ (wt $/ \mathrm{vol})$ beef extract, $0.2 \%$ (wt/vol) $\mathrm{N}-\mathrm{Z}$ amine type $\mathrm{A}$, and $1.0 \%$ (wt/vol) glucose. Cells were harvested during the exponential growth phase, centrifuged to pellet the wet cell mass, and washed twice with TE buffer ( $\mathrm{pH} 7.2)$.

Extraction of DNA, PCR amplification, and sequencing of rRNA genes. Cells were disrupted with a French pressure cell at $12,000 \mathrm{lb} / \mathrm{in}^{2}$, and extraction of the resulting lysate, once with TE-equilibrated phenol and once with chloroform-isoamyl alcohol $(24: 1, \mathrm{vol} / \mathrm{vol})$, was followed by ethanol precipitation. An aliquot of this DNA preparation was redissolved in sterile distilled water and reprecipitated by using polyethylene glycol 8000 (14). The resulting pellet was resuspended in distilled water, and $1-\mu 1$ (10- to $100-n g)$ portions were added to PCR mixtures by using a hot start (12) and primers designed to amplify almost the entire $16 \mathrm{~S}$ rRNA gene (5). The amplified products were precipitated and directly sequenced (5).

Phylogenetic analysis. The $16 \mathrm{~S}$ rRNA gene sequence $(1,438$ bases) of Pseudoamycolata halophobica was aligned with sequences of members of the family Pseudonocardiaceae $(2,8,9$, 21), and Tsukamurella paurometabolum (4) was used as an outgroup. Regions of rRNA sequence which could not be unambiguously aligned were removed, and 916 sequence positions were used to calculate a distance matrix by using the algorithm of Jukes and Cantor (13) in PHYLIP, version 3.5c (10). In order to assess the stability of the phylogenetic trees, the sequence data were resampled 100 times by using the bootstrapping procedure (SEQBOOT [10]). Tree diagrams were constructed by using the neighbor-joining method in (19) PHYLIP. For parsimony analysis we used the PAUP program (20).

Nucleotide sequence accession number. The sequence of Pseudoamycolata halophobica has been deposited in the EMBL data base under accession number Z14111.

\section{RESULTS AND DISCUSSION}

The sequencing method which we used generated 1,438 bases of 16S ribosomal DNA sequence of Pseudoamycolata halophobica. This sequence exhibited between 95.4 and $96.6 \%$ similarity (for 1,346 to 1,438 bases) to sequences obtained for 


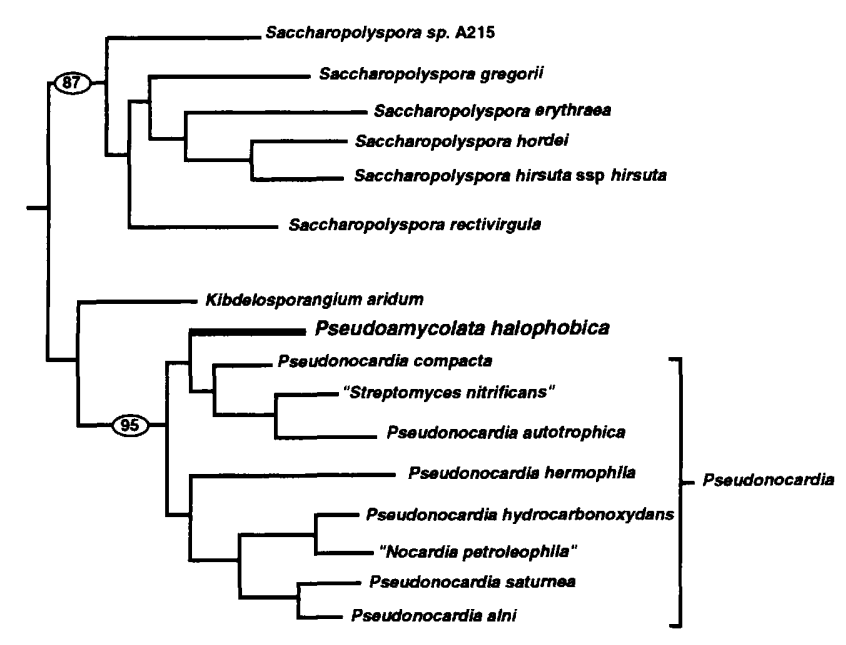

0.010
$\mathbf{K} n u c$

FIG. 1. Distance tree produced by using neighbor joining, showing the phylogenetic position of Pseudoamycolata halophobica. An alignment of 916 bases was used in the analysis. The numbers at the nodes indicate the levels of bootstrap support (based on data for 100 replicates) for the groups to the right of the nodes. Scale bar (for horizontal distances) indicates 0.01 substitution per nucleotide position.

members of the genus Pseudonocardia. All of the phylogenetic trees placed Pseudoamycolata halophobica close to or within the radiation defined by species of the genus Pseudonocardia and at some distance from members of the genus Amycolatopsis. Distance matrix analysis (Fig. 1) and bootstrapping analysis consistently placed Pseudoamycolata halophobica together with Pseudonocardia species (95\% of trees). Although the precise position of Pseudoamycolata halophobica was not resolved, this taxon most commonly appeared as a branch on the lineage leading to Pseudonocardia compacta, "Streptomyces nitrificans," and Pseudonocardia autotrophica (39\% of trees).

Over the past few years the concept of polyphasic taxonomy has been adopted as a guiding principle for good bacterial classification (18). This concept advocates that the most stable and useful taxonomy is one that utilizes genotypic and phenotypic criteria and does not put undue weight on any one type of evidence. On the basis of such criteria, it is proposed in the accompanying paper that the genera Amycolata and Pseudonocardia should be combined in a redefined genus, Pseudonocardia (21). In contrast, the genus Pseudoamycolata was created for strains which differed from species of the genus Amycolata (which are now classified as members of the genus Pseudonocardia) by a single chemical characteristic: they lacked phosphatidylcholine. We did not detect phosphatidylcholine in the type strain of Pseudoamycolata halophobica (unpublished data). Phosphatidylcholine is produced in bacteria by sequential methylation of phosphatidylethanolamine (11), and it is conceivable (but not proven in this case) that relatively minor mutations could prevent this transformation. In any case, the absence of a single characteristic should not be used to determine relationships. This was demonstrated when the amycolate Corynebacterium species, Corynebacterium amycolatum (Collins et al. 1988), was described (3). This new species had chemotaxonomic characteristics consistent with inclusion in the genus Corynebacterium, yet it did not contain mycolic acids (3). Apart from the absence of phosphatidylcho- line, Pseudoamycolata halophobica resembles species which are now classified as members of the genus Pseudonocardia (21) in all other characteristics. This organism has the same morphology as Pseudonocardia species and possesses cultural, physiological, fatty acid, menaquinone composition, and moles percent $\mathrm{G}+\mathrm{C}$ of the DNA, characteristics which are consistent with membership in the genus Pseudonocardia $(1,6)$. We have now shown that it is closely related to members of the genus Pseudonocardia on the basis of $16 \mathrm{~S}$ rRNA sequences.

A major goal of taxonomy is to produce stable classifications, and name changes should not be undertaken lightly. Balanced against this is the desire to reflect natural relationships. In the case described above, we believe that the weight of genotypic and phenotypic evidence argues strongly for reclassification of Pseudoamycolata halophobica. To this end, we propose that Pseudodoamycolata halophobica (Akimov, Evtushenko, and Dobritsa 1989) should be reclassified as Pseudonocardia halophobica. The inclusion of Pseudonocardia halophobica in the genus Pseudonocardia (Warwick, Bowen, McVeigh, and Embley 1994) means that the genus description should be emended to include strains which do not contain phosphatidylcholine. The species description remains the same as the description published previously (1).

\section{ACKNOWLEDGMENTS}

The phylogenetic analyses were carried out by using the SERC SEQNET facility at Daresbury, United Kingdom.

This project was funded by Glaxo Group Research.

\section{REFERENCES}

1. Akimov, V. N., L. I. Evtushenko, and S. V. Dobritsa. 1989. Pseudoamycolata halophobica gen. nov., sp. nov. Int. J. Syst. Bacteriol. 39:457-461.

2. Bowen, T., E. Stackebrandt, M. Dorsch, and T. M. Embley. 1989. The phylogeny of Amycolata autotrophica, Kibdelosporangium aridum and Saccharothrix australiensis. J. Gen. Microbiol. 135:25292536.

3. Collins, M. D., R. A. Burton, and D. Jones. 1988. Corynebacterium amycolatum sp. nov., a new mycolic acid-less Corynebacterium species from human skin. FEMS Microbiol. Lett. 49:349-352.

4. Collins, M. D., J. Smida, M. Dorsch, and E. Stackebrandt. 1988. Tsukamurella gen. nov. harboring Corynebacterium paurometabolum and Rhodococcus aurantiacus. Int. J. Syst. Bacteriol. 38: 385-391.

5. Embley, T. M. 1991. The linear PCR reaction: a simple and robust method for sequencing amplified rRNA genes. Lett. Appl. Microbiol. 13:171-174.

6. Embley, T. M. 1992. The family Pseudonocardiaceae, p. 996-1027. In A. Balows, H. G. Trüper, M. Dworkin, W. Harder, and K. H. Schleifer (ed.), The prokaryotes, 2nd ed., vol. 1 Springer-Verlag, New York.

7. Embley, T. M., A. G. O'Donnell, J. Rostron, and M. Goodfellow. 1988. Chemotaxonomy of wall type IV actinomycetes which lack mycolic acids. J. Gen. Microbiol. 134:953-960.

8. Embley, T. M., J. Smida, and E. Stackebrandt. 1988. The phylogeny of mycolateless wall chemotype IV actinomycetes and description of Pseudonocardiaceae fam. nov. Syst. Appl. Microbiol. 11: 44-52.

9. Embley, T. M., J. Smida, and E. Stackebrandt. 1988. Reverse transcriptase sequencing of ribosomal RNA from Pseudonocardia thermophila, Faenia rectivirgula and Saccharopolyspora hirsuta. J. Gen. Microbiol. 134:961-966.

10. Felsenstein, J. 1993. PHYLIP (phylogenetic inference package) version 3.5c. Department of Genetics, University of Washington, Seattle.

11. Harwood, J. L., and N. J. Russell. 1984. Lipids in plants and microbes. George Allen and Unwin, London.

12. Hosta, L., and P. Flicke. 1992. Enhancement of specificity and 
yield in PCR, p. 1-5. In Editorial comments, vol. 18. United States Biochemical Corp.

13. Jukes, T. H., and C. R. Cantor. 1969. Evolution of protein molecules, p. 21-132. In H. N. Munro (ed.), Mammalian protein metabolism. Academic Press, New York.

14. Kusukawa, N., T. Uemori, K. Asada, and I. Kato. 1990. Rapid and reliable protocol for direct sequencing of material amplified using the polymerase chain reaction. Biotechniques 9:66-72.

15. Lechevalier, M. P., C. deBievre, and H. A. Lechevalier. 1977. Chemotaxonomy of aerobic actinomycetes: phospholipid composition. Biochem. Syst. Ecol. 5:249-260.

16. Lechevalier, M. P., and H. A. Lechevalier. 1970. Chemical composition as a criterion in the classification of aerobic actinomycetes. Int. J. Syst. Bacteriol. 20:435-443.

17. Lechevalier, M. P., H. Prauser, D. P. Labeda, and J. S. Ruan. 1986. Two new genera of nocardioform actinomycetes: Amycolata gen. nov. and Amycolatopsis gen. nov. Int. J. Syst. Bacteriol. 36:29-37.

18. Murray, R. G. E., D. J. Brenner, R. R. Colwell, P. de Vos, M. Goodfellow, P. A. D. Grimont, N. Pfennig, E. Stackebrandt, and
G. A. Zavarzin. 1990. Report of the Ad Hoc Committee on Approaches to Taxonomy within the Proteobacteria. Int. J. Syst. Bacteriol. 40:213-215.

19. Saitou, N., and M. Nei. 1987 . The neighbor joining method: a new method for constructing phylogenetic trees. Mol. Biol. Evol. 4:406-425.

20. Swofford, D. 1991. PAUP: phylogenetic analysis using parsimony, version 3.0. Illinois Natural History Survey, Champaign.

21. Warwick, S., T. Bowen, H. P. McVeigh, and T. M. Embley. 1994. A phylogenetic analysis of the family Pseudonocardiaceae and the genera Actinokineospora and Saccharothrix with 16S rRNA sequences and a proposal to combine the genera Amycolata and Pseudonocardia in an emended genus Pseudonocardia. Int. J. Syst. Bacteriol. 44:293-299.

22. Witt, D., and E. Stackebrandt. 1990. Unification of the genera Streptoverticillium and Streptomyces and amendation of Streptomyces Waksman and Henrici 1943, 339 ${ }^{\text {AL }}$. Syst. Appl. Microbiol. 13:361-371. 